\title{
EFFECTS OF CHEMICAL POLLUTION ON THE ACTIVITIES OF HEPATIC XENOBIOTIC METABOLIZING ENZYMES IN FISH FROM THE RIVER RHÔNE
}

\author{
G. MONOD*, A. DEVAUX and J.L. RIVIERE
}

Institut National de la Recherche Agronomique, Laboratoire d'Ecotoxicologie INRA-ENVL, BP 31, 69752 Charbonnières Cedex (France)

(Received October 24th, 1987; accepted December 14th, 1987)

\begin{abstract}
Polychlorobiphenyl (PCBs) levels and hepatic xenobiotic metabolizing enzyme activities were measured in fish from three locations of the River Rhône to study the consequences of a constant loading of PCBs from a PCB incineration plant. Our results show that levels of PCBs and enzyme activities were higher in fish living downstream from the plant than in fish from two locations upstream, suggesting enzyme induction by PCBs (known to be potent inducers in laboratory conditions). Enzyme activities were studied in spring and autumn in three species: nase (Chondrostoma nasus), roach (Rutilus rutilus) and grayling (Thymallus thymallus). Induction was observed for three cytochrome P-450-dependent monooxygenase activities (MO), i.e. 7-ethoxyresorufin $O$ deethylase (EROD), aryl hydrocarbon hydroxylase (AHH) and 7-ethoxycoumarin $O$-deethylase (ECOD). There was a close correlation between EROD and AHH activities (for all species). Glutathione $S$-transferase activities were also shown to be related to the PCB levels. Conversely, cytochrome P-450 content and benzphetamine $N$-demethylase activity were not "PCB level-dependent". This study clearly demonstrates a close relationship between PCB contamination and MO activities in fish from the field and thus clearly emphasizes the interest in $\mathrm{MO}$ as a monitoring tool for estimating water quality.
\end{abstract}

\section{INTRODUCTION}

Many studies of the pollution of the aquatic environment by micropollutants deal with measurement of contamination levels in living organisms. Such studies are often unable to predict toxicological consequences. Recently, suggestions were made that changes in various physiological and biochemical parameters may be of value as early warning systems to detect the sublethal effects of pollutants. An assessment of the activity of xenobiotic metabolizing enzymes may be of value.

These enzymes are primarily hepatic cytochrome P-450-dependent monooxygenases (MO), which transform lipid-soluble xenobiotics into more watersoluble products that can be easily excreted from the organism or conjugated with endogenous molecules to form derivatives such as glucuronides or

* Author to whom correspondence should be addressed. 
glutathione conjugates. Many xenobiotics are converted to less biologically active compounds by xenobiotic metabolizing enzymes. However, the metabolic activation of carcinogens and some toxic chemicals appears to involve MO (Guengerich and Liebler, 1985). Furthermore, MO activities are highly inducible by many pollutants and could provide a valuable indication of the presence of such compounds in the field and an assessment of early toxic effects on living organisms (for a review, see Payne et al., 1987).

Many laboratory experiments have demonstrated the inducibility of MO activities in fish by petroleum hydrocarbons (Payne and Fancey, 1982), polycyclic aromatic hydrocarbons (PAHs) and polychlorinated biphenyls (PCBs) (Förlin, 1980; Andersson et al., 1985; Kobayashi et al., 1987). Induction of conjugating activities has also been observed, but to a lesser extent than MO activities (Andersson et al., 1985). Field studies have been seldom and have been mainly carried out on sea fish following hydrocarbon pollution (Payne, 1976; Davies and Bell, 1984). In the fresh water ecosystem, domestic and industrial loads were demonstrated to be responsible for the induction of MO activities in fish from a Yugoslavian river (Kezic et al., 1983). Recently, Melancon et al. (1987) observed induction of hepatic microsomal 7-ethoxyresorufin $O$ deethylase activity in carp exposed to river water highly suspected to be contaminated by PCBs. These pollutants are well-known potent inducers in fish after experimental exposure, but it was the first study which clearly proposed the involvement of PCBs present in the field as the main cause of induction of MO activities in fish. Nevertheless, the authors did not analyse the PCB levels in the river water, nor in the affected fish.

In our laboratory, preliminary analyses have demonstrated high levels of PCBs in fish caught downstream from a PCB incineration plant close to the River Rhône, and a high level of PCBs was detected in the effluents of this plant (unpublished data). The present work was undertaken to study the impact of this discharge of PCBs into the River Rhône on the hepatic xenobiotic metabolizing enzymes of three species of fish. Fish were collected in a polluted area downstream from the plant and in two locations upstream of the plant, i.e not exuosed to PCB loading. Hepatic xenobiotic metabolizing enzyme activities (MO and glutathione $S$-transferase activities) were compared, as well as PCB levels, in fish from the three locations.

MATERIALS AND METHODS

\section{Animals}

Roach (Rutilus rutilus), nase (Chondrostoma nasus) and grayling (Thymallus thymallus) were caught with a net or by electrofishing at stations (Pont d'Ain, Miribel and Pont de Lucey) on the River Rhône during the spring and autumn of 1986 (Fig. 1). Only results related to fish caught during the spring are presented in this paper, because results obtained during the autumn lead to a similar interpretation. Roach were 4-5 years old (average body 


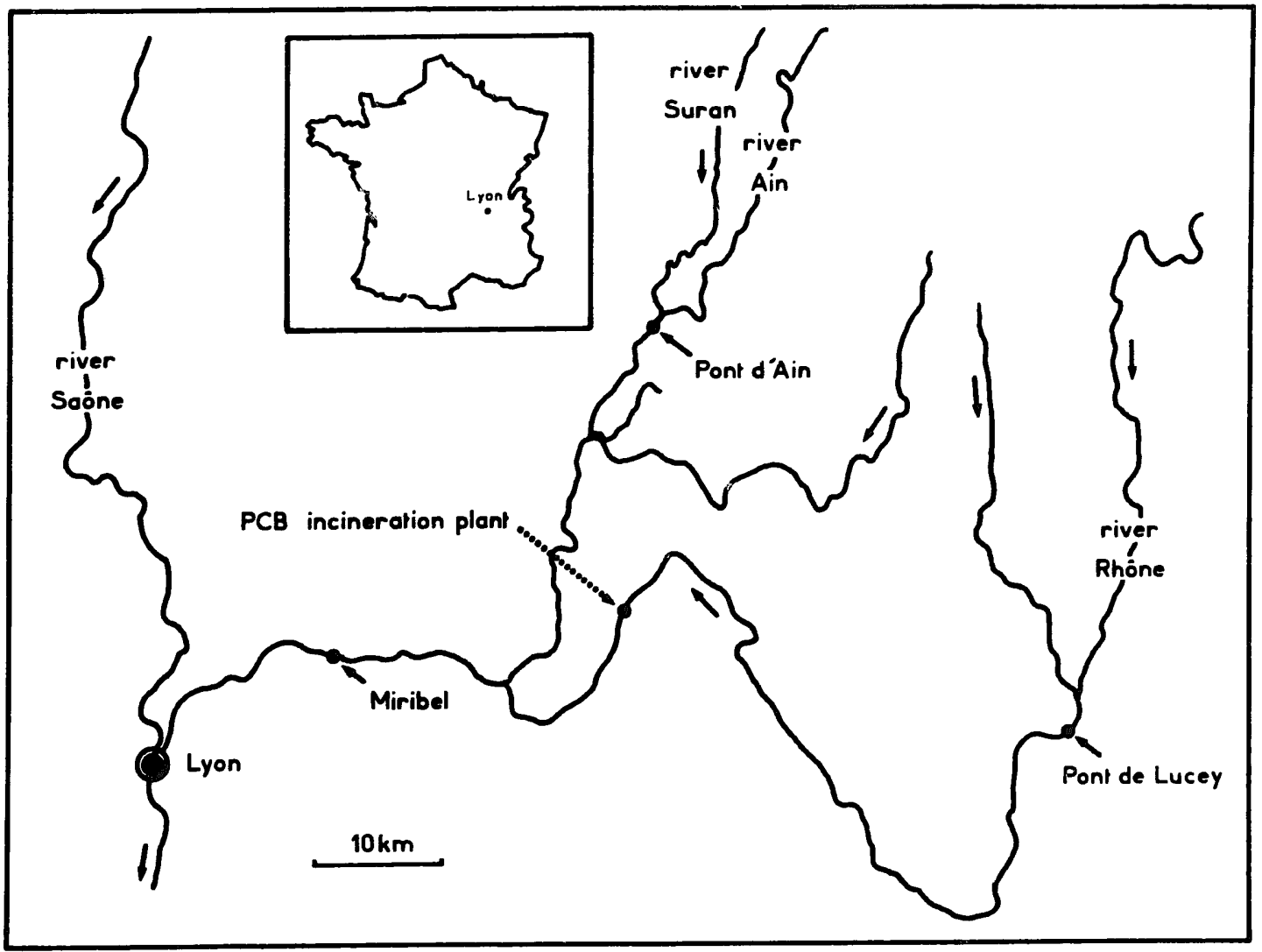

Fig. 1. Geographical locations of the three stations on the River Rhône where the fish were caught.

weight, $207 \mathrm{~g}$ ), grayling 3-4 years old (average body weight, $357 \mathrm{~g}$ ) and nase 7-8 years old (average body weight, $771 \mathrm{~g}$ ). Age was determined by scalimetry. When caught, the fish were slaughtered; the liver was then removed, wrapped in aluminium foil and frozen in liquid nitrogen until processed for the preparation of microsomes (no more than 3 days following fish collection).

\section{Preparation of subcellular fractions}

Hepatic microsomes were prepared as previously described (Monod et al., 1987). The post-microsomal fraction was also collected and stored at $-80^{\circ} \mathrm{C}$ until analysis of glutathione $S$-transferase activity. No loss of enzymatic activity was found up to 3 months.

\section{Dosage of PCBs}

PCB analyses were performed following the methud previously described (Devaux and Monod, 1987) on pooled edible portions of males and females of each species. 


\section{Chemicals}

Glucose 6-phosphate (G 6-P), glucose 6-phosphate dehydrogenase (G 6-PDH), nicotinamide dinucleotide phosphate (NADP), dithiothreitol (DTT) and glutathione were purchased from Boehringer-Mannheim, France. 7-Ethoxycoumarin was synthesized by the method of Ullrich and Weber (1972). 7-Ethoxyresorufin (7-ethoxyphenoxazone) was synthesized by the method of Prough et al. (1978) from resorufin (7-hydroxyphenoxazone, Eastman Organic Chemicals, Rochester, NY). Benzo[a]pyrene, 1-chloro-2,4-dinitrobenzene (CDNB), $x$-naphthoflavone and metyrapone were from Aldrich, France. Benzphetamine hydrochloride was from Laboratoires Upjohn, France. Other analytical-grade chemicals were purchased commercially.

\section{Enzyme assays}

The activities of benzo[a]pyrene hydroxylase (AHH), 7-ethoxycoumarin $O$ deethylase (ECOD) and 7-ethoxyresorufin $O$-deethylase (EROD) were assayed according to Monod et al. (1987) at $\mathrm{pH}$ 7.4. Benzphetamine $N$-demethylase (BeND) assay was performed according to Werringloer (1978). Glutathione $S$-transferase (GSH-t) was determined following the method of Habig et al. (1974) with CDNB as a substrate. NADPH-cytochrome $c$ reductase activity (cyt. c reductase) was assayed as previously described (Monod et al., 1987) at pH 7.7. All reactions were performed at environmental temperatures, i.e. $10^{\circ} \mathrm{C}$ in spring. Results are expressed as arbitrary fluorescence units (FU)/min/mg protein for $\mathrm{AHH}$, as $\mathrm{nmol} / \mathrm{min} / \mathrm{mg}$ protein for cyt. $c$ reductase, as $\mu \mathrm{mol} / \mathrm{min} / \mathrm{mg}$ protein for GSH-t and as pmol/min/mg protein for EROD, ECOD and BeND. The extinction coefficient of resorufin was $73 \mathrm{mM}^{-1}$ (Klotz et al., 1984). Cytochrome P-450 (cyt. P-450) content was measured according to Matsubara et al. (1976). Protein was determined by the method of Hartree (1972) with bovine serum albumin as a standard. All analyses were performed in duplicate. All reactions were linear with respect to time and protein concentration.

\section{RESULTS}

PCB concentrations in the fish from the three locations are given in Table 1. No statistical differences were found between males and females regarding PCB contents for each fish species (data not shown); thus, no further distinction was made between the two sexes. The level of contamination is much higher in fish from Miribel than those from other locations. For example, we found PCB concentrations to be 8.6- and 5.1-fold higher in nase from Miribel than from Pont d'Ain and Pont de Lucey, respectively. There are no significant differences between species.

Table 2 shows specific activities of AHH, EROD, ECOD and BeND. AHH, EROD and ECOD activities are consistently lower in fish from Pont d'Ain and Pont de Lucey than in fish from Miribel. In contrast, BeND activities do not 
TABLE 1

Concentrations of PCBs in muscle of three species of fish caught at three locations on the River Rhône

\begin{tabular}{llll}
\hline & Station & & \\
\cline { 2 - 4 } & Miribel & Pont d'Ain & Pont de Lucey \\
\hline Roach & $5.32^{\mathrm{a}}(9)^{\mathrm{b}}$ & & $1.62(9)$ \\
Nase & $4.55(8)$ & $0.53(8)$ & $0.90(10)$ \\
Grayling & $6.00(6)$ & $0.66(6)$ & \\
\hline
\end{tabular}

${ }^{a}$ Concentrations expressed in $\mathrm{mg} / \mathrm{kg}$ fresh weight (ppm).

${ }^{b}$ Number of fish pooled for analysis.

follow such a trend, except in the case of grayling. Cyt. P-450 content, cyt. $c$ reductase activities and protein concentrations are shown in Table 3. Results show higher values for fish from Miribel than for fish from the other two locations. Glutathione $S$-transferase activities again reach maximum values in the three species from Miribel as compared with Pont de Lucey and Pont d'Ain (Table 4).

Close correlations between EROD and AHH activities are found for grayling, nase and roach (Fig. 2), suggesting a similar response of both enzymes to environmental conditions.

To compare the qualitative composition of pools of cyt. P-450 in fish caught at different locations, assays were conducted with two diagnostic inhibitors of

\section{TABLE 2}

AHH, EROD, ECOD and BeND activities in liver of fish from three locations on the River Rhône

\begin{tabular}{lllrl}
\hline & Station & \multicolumn{1}{l}{ Nase } & Grayling & \multicolumn{1}{l}{ Roach } \\
\hline AHH & Pt d'Ain & $0.63 \pm 0.05(8)^{\star \star \star}$ & $13.7 \pm 0.78(6)^{\star \star}$ & \\
(FU/min- & Miribel & $2.87 \pm 0.40(8)$ & $24.3 \pm 2.08(6)$ & $3.65 \pm 0.29(9)$ \\
/mg protein) & Lucey & $0.66 \pm 0.09(10)^{\star \star}$ & $5.7 \pm 0.64(7)^{\star \star}$ & $0.46 \pm 0.08(9)^{\star \star}$ \\
& & & & \\
EROD & Pt d'Ain & $13 \pm 1(8)^{\star \star}$ & $136 \pm 31(6)^{\star \star}$ & \\
(pmol/min- & Miribel & $36 \pm 6(8)$ & $480 \pm 73(6)$ & $52 \pm 6(9)$ \\
/mg protein) & Lucey & $4 \pm 1(10)^{\star \star}$ & $76 \pm 16(7)^{\star \star}$ & $7 \pm 1(9)^{\star \star}$ \\
& & & & \\
ECOD & Pt d'Ain & $39 \pm 5(8)$ & $39 \pm 8(6)^{\star \star}$ & $76 \pm 4(9)$ \\
(pmol/min- & Miribel & $47 \pm 6(8)$ & $220 \pm 50(6)$ & $29 \pm 4(9)^{\star \star}$ \\
/mg protein) & Lucey & $23 \pm 3(10)^{\star \star}$ & $32 \pm 5(7)^{\star \star}$ & \\
& & & & \\
BeND & Pt d'Ain & $160 \pm 20(8)^{\star \star}$ & $70 \pm 7(6)^{\star \star}$ & $45 \pm 12(8)$ \\
(pmol/min- & Miribel & $69 \pm 11(8)$ & $180 \pm 18(5)$ & $168 \pm 31(9)^{\star \star}$ \\
/mg protein) & Lucey & $99 \pm 16(10)$ & $83 \pm 11(7)^{\star \star}$ &
\end{tabular}

${ }^{a}$ Mean \pm SEM (number of fish). Significantly different from values obtained at Miribel. Student's $t$ test: ${ }^{\star \star} p<0.01$. 


\section{TABLE 3}

Protein concentrations, cyt. P-450 contents and cyt. $c$ reductase activities in the liver of fish from three locations on the River Rhône

\begin{tabular}{cllll}
\hline & Station & Nase & Grayling & Roach \\
\hline & Pt d'Ain & $18.4 \pm 1.17(8)^{\mathrm{a}}$ & $28.0 \pm 1.22(6)^{\star *}$ & \\
Protein & Miribel & $17.4 \pm 1.59(8)$ & $15.6 \pm 0.78(6)$ & $28.1 \pm 1.03(9)$ \\
(mg/g liver) & Lucey & $24.0 \pm 1.14(10)^{\star *}$ & $25.5 \pm 0.65(7)^{\star *}$ & $19.8 \pm 1.23(9)^{\star *}$ \\
& Pt d'Ain & $0.20 \pm 0.01(8)$ & $0.35 \pm 0.04(6)^{\star *}$ & \\
Cyt. P-450 & Miribel & $0.21 \pm 0.02(8)$ & $1.28 \pm 0.19(6)$ & $0.30 \pm 0.02(9)$ \\
(nmol/mg protein) & Lucey & $0.13 \pm 0.01(10)^{\star *}$ & $0.24 \pm 0.02(7)^{\star *}$ & $0.19 \pm 0.02(9)^{\star *}$ \\
Cyt. c reductase & Pt d'Ain & $37.0 \pm 3.5(8)^{\star}$ & $20.9 \pm 2.1(6)^{\star *}$ & \\
(nmol/min- & Miribel & $26.0 \pm 1.6(8)$ & $44.4 \pm 2.2(6)$ & $23.8 \pm 2.0(9)$ \\
/mg protein & Lucey & $26.7 \pm 2.5(10)$ & $20.5 \pm 1.2(6)^{\star *}$ & $18.8 \pm 1.4(9)$ \\
\hline
\end{tabular}

${ }^{a}$ Mean \pm SEM (number of fish). Significantly different from values obtained at Miribel. Student's $t$ test: ${ }^{*} p<0.05,{ }^{* *} p<0.01$.
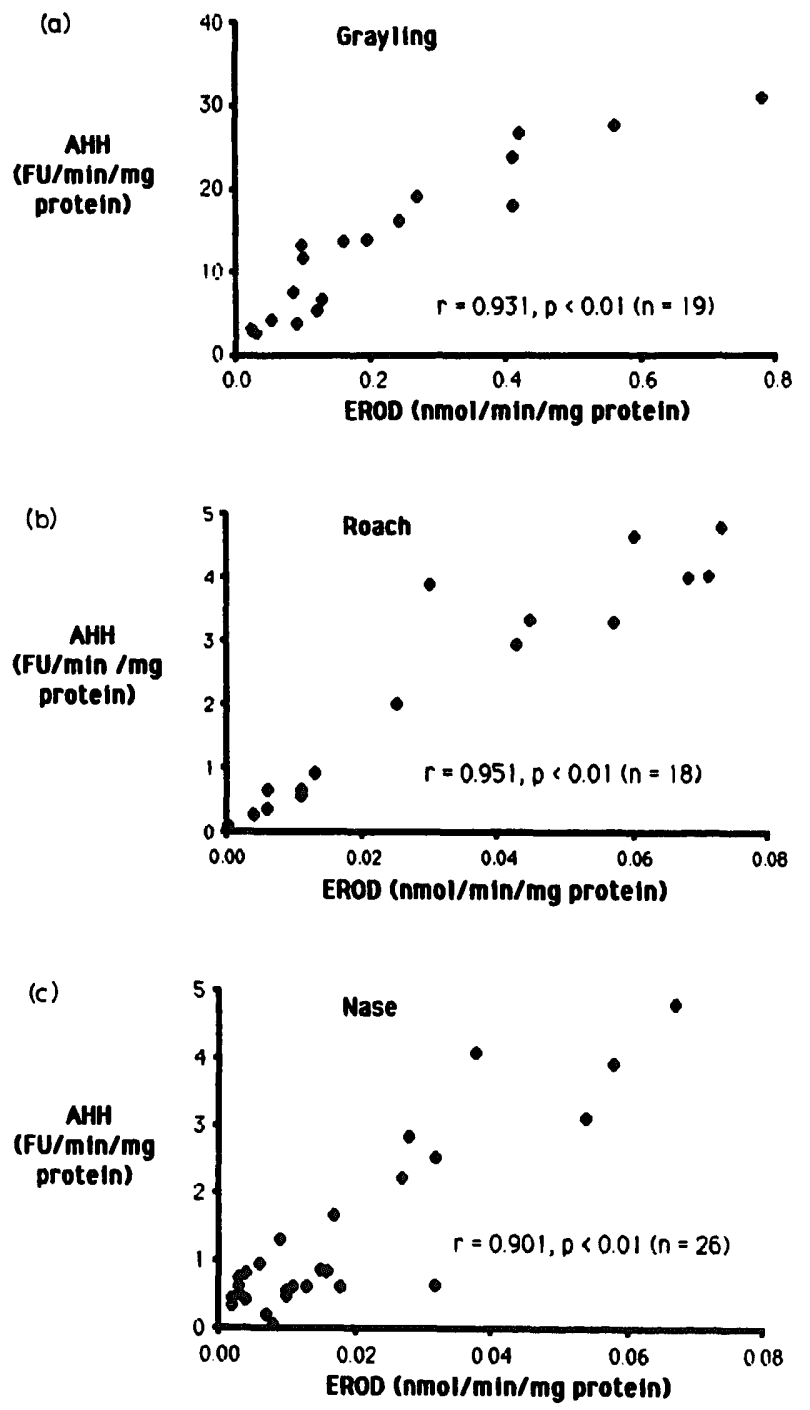

Fig. 2. Relationship between EROD and AHH activities in the liver of grayling, roach and nase from the River Rhône. 
TABLE 4

GSH-t activity in the liver of fish from three locations on the River Rhône

\begin{tabular}{|c|c|c|c|c|}
\hline & Station & Nase & Grayling & Roach \\
\hline $\begin{array}{l}\text { GSH-t } \\
\text { ( } \mu \mathrm{mol} / \mathrm{min}- \\
\text { /mg protein) }\end{array}$ & $\begin{array}{l}\text { Pt d'Ain } \\
\text { Miribel } \\
\text { Lucey }\end{array}$ & $\begin{array}{l}1.34 \pm 0.12(8)^{\mathrm{a} \star \star} \\
2.74 \pm 0.27(8) \\
1.57 \pm 0.21(10)^{\star \star}\end{array}$ & $\begin{array}{l}0.62 \pm 0.10(6)^{\star \star} \\
1.11 \pm 0.04(6) \\
0.70 \pm 0.08(7)^{\star \star}\end{array}$ & $\begin{array}{l}3.14 \pm 0.26(9) \\
1.64 \pm 0.28(9)^{\star \star}\end{array}$ \\
\hline
\end{tabular}

${ }^{\text {a }}$ Mean \pm SEM (number of fish). Significantly different from values obtained at Miribel. Student's $t$ test: ${ }^{* *} p<0.01$.

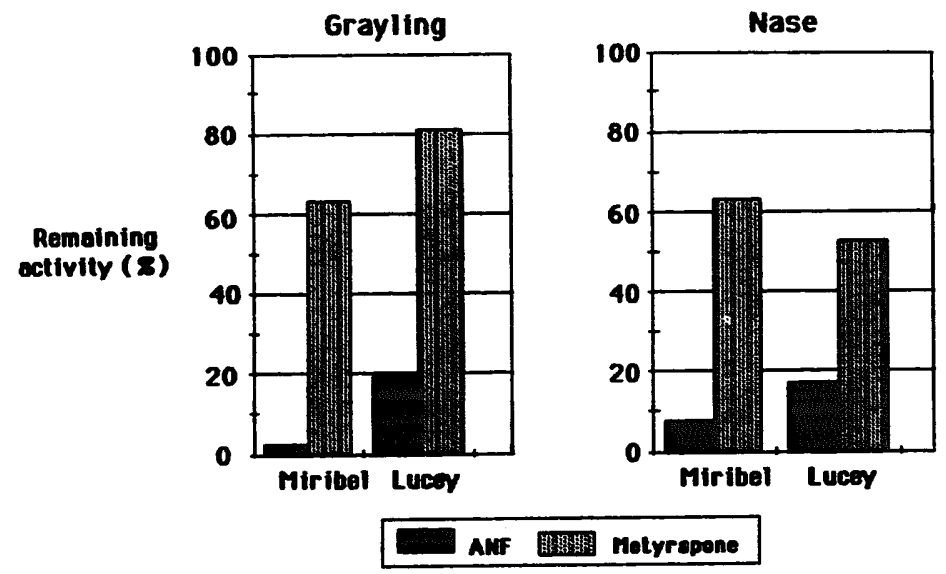

Fig. 3. In vitro inhibition of EROD by $10^{-6} M \alpha$-naphthoflavone (ANF) and $10^{-4} M$ metyrapone using liver microsomes from grayling and nase caught at two stations on the River Rhône, Miribel (high contamination by PCBs) and Pont de Lucey (low contamination by PCBs), respectively. The results are expressed as remaining enzyme activity compared with a vehicle (DMSO)-treated sample (100\%). The percentage of inhibition was calculated using the mean of the specific activities calculated from at least six fish.

MO activities, $\alpha$-naphthoflavone and metyrapone. Figure 3 illustrates the results of these experiments, showing EROD activity in grayling and nase from Miribel and Pont de Lucey. In both species, but mostly in grayling, $\alpha$-naphthoflavone seems to inhibit EROD activity more strongly in fish from Miribel than in those from Pont de Lucey. In contrast, the rate of inhibition by metyrapone remains low and no differences were found between locations.

\section{DISCUSSION}

These results confirm our preliminary analysis of the pollution of the River Rhône by PCBs. Fish collected downstream from the incineration plant have a much higher PCB concentration than fish caught upstream. PCB levels observed in edible portions of fish from Miribel are 2- to 3-fold higher than the U.S. Food and Drug Administration tolerance (2.0 ppm) and must be considered as very high compared with other ecosystems (Devaux and Monod, 1987). Such levels question the suitability of these fish for human consumption (fish are usually caught by amateur and professional fishermen) and the ecotoxicological consequences of this pollution. 
MO activities have previously been characterized in these species of fish (Monod et al., 1987). Classically, MO inducers are divided into two main groups typified by phenobarbital (PB) and 3-methylcholanthrene (MC). Cytochromes P-448 are induced by MC and cytochromes P-450 are induced by PB (Nebert and Negishi, 1982). There are major differences in substrate specificities between the induced cyt. P-448 and cyt. P-450 enzymes (AHH and EROD are typically MC-induced enzymes; BeND is mainly induced by PB). PCBs are potent inducers of MO activities in many organisms (Safe, 1984). In mammals, it was observed that the microsomal enzyme inducing activity of commercial mixtures of PCBs resembles the effects of PB plus MC (coadministered); nevertheless, it seems that PCBs induce only cyt. P-448 in fish (Elcombe et al., 1979). Generally, fish appear to be refractive to PB-type induction and only one study has demonstrated the induction of a P-450-type activity (BeND) by pregnenolone-16 $\alpha$-carbonitrile in rainbow trout (Vodicnik and Lech, 1983).

Our study demonstrates a close relationship between the high levels of PCBs and cyt. P-448-dependent activities found in fish from the River Rhône, whatever the species. PCBs were present in fish collected at every location, but in much greater concentrations in fish from Miribel, correlating well with the finding of the highest EROD and AHH activities. This justifies the interest in MO as a monitoring tool for estimating water quality (Payne et al., 1987). Cyt. P-450 content seems to be a less sensitive indicator than measurement of MO activities. As previously reported by Elcombe et al. (1979), BeND did not seem able to respond to PCB contamination. Cytosolic GSH-t activity followed the pattern of inducible-MO activities, i.e. the highest activities were found in fish from Miribel. This last result is in accordance with experimental demonstration of induction of GSH-t activity by PCBs in rainbow trout and carp (Andersson et al., 1985; Kobayashi et al., 1987).

We must remember the diversity of chemical pollutants present in natural water. Consequently, it could be speculative to propose a cause-effect relationship between PCB contamination of fish from the River Rhône and their hepatic MO activities. It has been shown that incineration of PCBs can initiate the synthesis of polychlorodibenzofurans (PCDFs) and polychlorodibenzodioxins (PCDDs) known as potent inducers of P-448-dependent activities (Rappe et al., 1983). Therefore, such compounds may be present and could lead to a PCB-like induction in fish downstream from the PCB incineration plant. Unfortunately, no analyses of PCDFs and PCDDs have been carried out in fish from the River Rhône until now. On the other hand, other compounds and particularly some metallic elements such as cadmium have the potential to inhibit the enzyme systems responsible for the biotransformation of the lipophilic organic xenobiotics in fish (Förlin et al., 1986). Cadmium and other metals have been detected in the effluents of the PCB incineration plant (unpublished data), probably as a result of destruction of waste material containing metals. Therefore, it may be postulated that fish from Miribel were also contaminated by metals, but no analyses were performed and thus no comparisons were made between locations upstream and downstream from the plant. Nevertheless, in 
spite of the potential inhibitory impact of the metallic pollution, it did not seem to be able to counterbalance the induction by detected PCBs.

Ecological and biological factors have been shown to promote variations in enzymatic biotransformation activities in fish. Activity levels seem greatly dependent on the season through the action of hormonal events and/or the variations of the water temperature (Koivusaari et al., 1981; Hansson et al., 1982; Lindström-Seppä, 1985). The interactions between these factors and induction of biotransformation enzymes have been investigated by some workers. Andersson and Koivusaari (1985) observed that induction rates of cytochrome P-450-dependent activities by $\beta$-naphthoflavone were markedly slower in cold- than in warm-acclimated rainbow trout. Nevertheless, induction reached the same level regardless of the two thermal treatments. Förlin and Lindman (1981) have shown that PCBs increase the hepatic cytochrome $\mathrm{P}-450$ content and $\mathrm{MO}$ activities in maturing female rainbow trout to a smaller degree than in juveniles. Conflicting results were obtained for marine fish. Walton et al. (1983) failed to observe induction of AHH in cunner by petroleum exposure at the time of spawning. Conversely, Collier et al. (1986) have shown that English sole is very responsive to induction of hepatic AHH activity during spawning. The fish studied in our work spawn in the spring, but we did not observe differences in the magnitude of induction of AHH, EROD and ECOD between fish caught in the spring and those caught in autumn. Therefore, it seems that the inducibility of MO activities in these species of fish remains at a significant level throughout the reproductive cycle.

In spite of the observed induction in all species studied exposed to the effluents of the PCB incineration plant, there were important variations between species concerning the level of enzyme activities. In the two seasons and the three locations, EROD and AHH activities were generally 3-to 10-times greater in grayling than in nase and roach, indicating possible differences between metabolizing capacity of salmonids and cyprinids. As this result was observed regardless of the location and the degree of pollution, interspecies variations could more probably be related to variations between constitutive metabolizing capacities than to variations between inducibility by pollutants. Differences were less pronounced for ECOD activity and did not seem to exist for BeND. On the other hand, GSH-t activity of grayling liver was half that of the cyprinid species, suggesting differences between cyprinids and salmonids in the balance between $\mathrm{MO}$ and conjugating activities.

Many authors have frequently used AHH activity (for a review, see Payne et al., 1987) as a sensitive indicator of MO induction. However, Elcombe et al. (1979) have shown that AHH and EROD could be induced simultaneously by PCBs. Furthermore, Vignier and Berthou (1986) have proposed that EROD could be a more sensitive indicator than AHH. Our results clearly demonstrate that there is a close relationship between hepatic EROD and AHH activities in roach, nase and grayling from the River Rhône. EROD seems to be a very useful indicator because of its high sensitivity, specificity and practicability of the reaction (Burke et al., 1985). 
It is obvious from our results that inducible-MO activities do not correlate with total cyt. P-450 contents. This is in accordance with results previously published by Elcombe et al. (1979) who did not observe an increase in total hepatic microsomal cyt. P-450 in rainbow trout experimentally exposed to PCBs, although AHH, EROD and ECOD were significantly increased, suggesting that the increased specific enzymatic activity is due to changes in the relative amounts of the involved forms of cyt. P-450 and/or the increased synthesis of new forms of the cytochrome exhibiting high affinity towards "P-448-like" substrates (Ioannides et al., 1984). In mammalian species, it is generally believed that cytochromes P-450 are preferably inhibited by metyrapone, while cytochromes P-448 are preferably inhibited by $\alpha$-naphthoflavone (Goujon et al., 1972). Förlin (1980) demonstrated that PCBs increased the inhibition of hepatic AHH activity by $\alpha$-naphthoflavone in rainbow trout. Similar results were obtained by Binder and Lech (1984) with fry from Lake Michigan lake trout exposed to PCBs. Our results are in accordance with such observations, since susceptibility of EROD towards inhibition by $\alpha$-naphthoflavone was 10- and 2.3-times greater in grayling and nase, respectively, from the highly PCB-polluted location (Miribel), than in fish from Lucey, suggesting influence of pollution on the synthesis of "P-448-like" forms of cyt. P-450.

It has been proposed that cyt. P-450 directs metabolism towards deactivation while, in contrast, cyt. P-448 directs metabolism towards the generation of toxic intermediates. Consequently, the induction of cyt. P-448 activities may constitute a useful index of the potential carcinogenicity/toxicity of chemicals whose activation is mediated by MO (Parke et al., 1986; Safe, 1987). Metabolic activation has been described in fish, and treatment with MC or PCBs has been shown to increase the mutagenicity of procarcinogens such as benzo[a]pyrene, 2-aminoanthracene and 2-acetylaminofluorene (Egaas and Varanasi, 1982; Miyauchi, 1984). In addition, a relation between induction of MO activities and impairment of fish reproduction has been proposed. Recently, Spies et al. (1984) found a correlation between hepatic AHH activity and percent of unfertilized eggs in the starry flounder Platichthys stellatus. Deleterious effects could originate from interaction between reactive compounds and gonadal macromolecules (Varanasi et al., 1982) and also, since steroids are substrates for some forms of cyt. P-450 (for a review, see Hall, 1985), from perturbation of hormonal levels (Sivarajah et al., 1978). Therefore, potential toxicological implications of the induction we observed in fish from the River Rhône are of concern.

PCBs were previously known as potent inducers of cyt. P-448 activities in fish exposed experimentally. This study shows the occurrence of potent induction in the field. Our data from more than $100 \mathrm{fish}$, demonstrate also that MO activities are useful indicators of water quality. Hepatic AHH, ECOD and EROD activities are able to detect pollution by MO inducers such as PCBs, but EROD activity could be the best indicator, and its induction could provide an important tool to estimate the magnitude of potential toxicological consequences. 


\section{ACKNOWLEDGEMENTS}

This work was supported in part by a CNRS/PIREN Program "Maitrise des ressources ichthyologiques". The authors also thank $P$. Buisson and $M$. Simeon for providing the fish, and Y. Bouvet, E. Pattée, H. Persat and H. Morandi for field assistance and cooperation.

\section{REFERENCES}

Andersson, T. and U. Koivusaari, 1985. Influence of environmental temperature on the induction of xenobiotic metabolism by $\beta$-naphthoflavone in rainbow trout, Salmo gairdneri. Toxicol. Appl. Pharmacol., 80: 43-50.

Andersson, T., M. Pesonen and C. Johansson, 1985. Differential induction of cytochrome P-450dependent monooxygenase, epoxide hydrolase, glutathione transferase and UDP-glucuronosyl transferase activities in the liver of the rainbow trout by $\beta$-naphthoflavone or Clophen A50. Biochem. Pharmacol., 34: 3309-3314.

Binder, R.L. and J.J. Lech, 1984. Xenobiotics in gametes of lake Michigan lake trout (Salvelinus namaycush) induce hepatic monooxygenase activity in their offspring. Fundam. Appl. Toxicol., 4: $1042-1054$.

Burke, M.D., S. Thompson, C.R. Elcombe, J. Halpert, T. Haaparanta and R. T. Mayer, 1985. Ethoxy-, pentoxy- and benzyloxyphenoxazones and homol ogues: a series of substrates to distinguish between different induced cytochromes P-450. Biochem. Pharmacol., 34: 3337-3345.

Collier, T.K., J.E. Stein, R.J. Wallace and U. Varanasi, 1986. Xenobiotic metabolizing enzymes in spawning English sole (Parophrys vetulus) exposed to organic-solvent extracts of marine sediments from contaminated and reference areas. Comp. Biochem. Physiol., 84C: 291-298.

Davies, J.M. and J.S. Bell, 1984. A comparison of the levels of hepatic aryl hydrocarbon hydroxylase in fish caught close to and distant from North sea oil fields. Mar. Environ. Res., 14: 23-45.

Devaux, A. and G. Monod, 1987. PCB and p.p'-DDE in Lake Geneva brown trout (Salmo trutta L.) and their use as bioenergetic indicators. Environ. Monit. Assess., 9: 105-114.

Egaas, E. and U. Varanasi, 1982. Effect of polychlorinated biphenyls and environmental temperature on in vitro formation of benzo(a)pyrene metabolites by liver trout (Salmo gairdneri). Biochem. Pharmacol., 31: 561-566.

Elcombe, C.R., R.B. Franklin and J.J. Lech, 1979. Induction of microsomal hemoprotein(s) P-450 in the rat and rainbow trout by polyhalogenated biphenyls. Ann. NY Acad. Sci., 320: 193-203.

Förlin, L., 1980. Effects of Clophen A50, 3-methylcholanthrene, pregnenolone-16 $\alpha$-carbonitrile, and phenobarbital on the hepatic microsomal cytochrome P-450 dependent monooxygenase system in rainbow trout, Salmo gairdneri, of different age and sex. Toxicol. Appl. Pharmacol., 54: $420-430$.

Förlin, L., C. Haux, L. Karlsson-Norrgren, P. Runn and A. Larsson, 1986. Biotransformation enzyme activities and histopat hology in r'ainbow trout, Salmo gairdneri, treated with cadmium. Aquat. Toxicol., 8: 51-64.

Förlin, L. and U. Lidman, 1981. Effects of Clophen A50 and 3-methylcholanthrene on the hepatic mixed function oxidase system in female rainbow trout, Salmo gairdneri. Comp. Biochem. Physiol., 70C: 297-300.

Goujon, F.M., D.W. Nebert and J.F. Gielen, 1972. Genetic expression of aryl hydrocarbon hydroxylase induction: IV. Interaction of various compounds with different forms of cytochrome P-450 and the effect on benzo(a)pyrene metabolism in vitro. Mol. Pharmacol., 3: 667-680.

Guengerich, F.P. and D.C. Liebler, 1985. Enzymatic activation of chemicals to toxic metabolites. CRC Crit. Rev. Toxicol., 14: 259-307.

Habig, W.H., M.J. Pabst and W.B. Jakoby, 1974. Glutathione S-transferases: the first enzymatic step in mercapturic acid formation. J. Biol. Chem., 249: 7130-7139. 
Hall, P.F., 1985. Role of cytochrome P-450 in the biosynthesis of steroid hormones. In: Vitamins and Hormones, Vol. 42. Academic Press, New York, pp. 315-368.

Hansson, T., L. Förlin, J. Rafter and J-A. Gustafsson, 1982. Regulation of hepatic steroid and xenobiotic metabolism in fish. In: E. Hietanen, M. Laitinen and O. Hänninen (Eds), Cytochrome P-450. Biochemistry, Biophysics and Environmental Implications. Elsevier Biomedical Press B.V., Amsterdam, pp. 217-224.

Hartree, E.F., 1972. Determination of protein: a modification of the Lowry method that gives a linear photometric response. Anal. Biochem., 48: 422-427.

Ioannides, C., P.Y. Lum and D.V. Parke, 1984. Cytochrome P-448 and the activation of toxic chemicals and carcinogens. Xenobiotica, 14: 119-137.

Kezic, N., S. Britvic, M. Protic, J.E. Simmons, M. Rijavec and R.K. Zahn, 1983. Activity of benzo(a)pyrene monooxygenase in fish from the Sava river, Yugoslavia: correlation with pollution. Sci. Total Environ., 27: 59-69.

Klotz, A.V., J.J. Stegeman and C. Walsh, 1984. An alternative 7-ethoxyresorufin O-deethylase activity assay: a continuous visible spectrophotometric method for measurement of cytochrome P.450 monooxygenase activity. Anal. Biochem., 140: 138-145.

Kobayashi, K., Y. Oshima, C. Tagushi and Y. Wang, 1987. Induction of drug-metabolizing enzymes by long-term administration of PCB and duration of their induced activities in carp. Bull. Jpn Soc. Sci. Fish., 53: 487-491.

Koivusaari, U., M. Harri and O. Hänninen, 1981. Seasonal variation of hepacic biotransformation in female and male rainbow trout (Salmo gairdneri). Comp. Biochem. Physiol., 70C: 149-157.

Lindström-Seppä, P., 1985. Seasonal variation of the xenobiotic metabolizing enzyme activities in the liver of male and female vendace (Coregonus albula L.). Aquat. Toxicol., 6: 323-331.

Matsubara, T., M. Koike, A. Touchi, Y. Tochini and K. Sugeno, 1976. Quantitative determi nation of cytochrome P-450 in rat liver homogenate. Anal. Biochem., 75: 596-603.

Melancon, M.J., S.E. Yeo and J.J. Lech, 1987. Induction of hepatic microsomal monooxygenase activity in fish by exposure to river water. Environ. Toxicol. Chem., 6: 127-135.

Miyauchi, M., 1984. Conversion of procarcinogens to mutagens by the S-9 fraction from the liver of rainbow trout (Salmo gairdneri): inducibility with PCB, 3-methylcholanthrene and phenobarbital and inhibition by metyrapone and $\alpha$-naphthoflavone. Comp. Biochem. Physiol., 79C: 363-367.

Monod, G., A. Devaux and J.L. Riviere, 1987. Characterization of some monooxygenase activities and solubilization of hepatic cytochrome P.450 in two species of freshwater fish, the nase (Chondrostoma nasus) and the roach (Rutilus rutilus). Comp. Biochem. Physiol., 88C: 83-89.

Nebert, D.W. and M. Negishi, 1982. Multiple forms of cytochrome P.450 and the importance of molecular biology and evolution. Biochem. Pharmacol., 31: 2311-2317.

Parke, D.V., C. Ioannides and D.F.V. Lewis, 1986. Structure-activity models for toxicity testing. In: C.M. Hodel (Ed), Toxicology in Europe in the Year 2000. Elsevier, Amsterdam, pp. 14-19.

Payne, J.F., 1976. Field evaluation of benzopyrene hydroxylase induction as a monitor for marine petroleum pollution. Science, 191: 945-946.

Payne, J.F. and L.L. Fancey, 1982. Effect of long term exposure to petroleum on mixed-function oxygenases in fish: further support for use of the enzyme system in biological monitoring. Chemosphere, 11: 207-213.

Payne, J.F., L.L. Fancey, A.D. Rahimtula and E.L. Porter, 1987. Review and perspective on the use of mixed-function oxygenase enzymes in biological monitoring. Comp. Biochem. Physiol., 86C: 233-245.

Prough, R.A., M.D. Burke and R.T. Mayer, 1978. Direct fluorometric methods for measuring mixed-function oxidase activity. In: S. Fleischer and L. Packer (Eds), Methods in Enzymology. Vol. LII, Part C., Academic Press, New York, pp. 372-377.

Rappe, C., S. Marklund, P.A. Bergquist and M. Hansson, 1983. Polychlorinated dibenzo-p-dioxins, dibenzofurans and other polynuclear aromatics formed during incinerations and PCB fires. In: Chlorinated Dioxins and Dibenzofurans in the Total Environment. Vol. 1. Butterworth's AnnArbor Science, Boston, pp. 99-124.

Safe, S., 1984. Polychlorinated biphenyls (PCI3s) and polybrominated biphenyls (PBBs): biochemistry, toxicology, and mechanism of action. CRC Crit. Rev. Toxicol., 13: 319-396. 
Safe, S., 1987. Determination of 2, 3, 7, 8-TCDD toxic equivalent factors (TEFs): support for the use of the in vitro AHH induction assay. Chemosphere, 16: 791-802.

Sivarajah, K., C.S. Franklin and W.P. Williams, 1978. The effects of polychlorinated biphenyls on plasma steroid levels and hepatic microsomal enzymes in fish. J. Fish Biol., 13: 401-409.

Spies, R.B., D.W. Rice Jr and R.R. Ireland, 1984. Preliminary studies of growth, reproduction and activity of hepatic mixed-function oxidase in Platichthys stellatus. Mar. Environ. Res., 14: 426-428.

Ullrich, V. and P. Weber, 1972. The $O$-dealkylation of 7-ethoxycoumarin by liver microsomes. Hoppe-Seyler's Z. Physiol. Chem., 353: 1171-1177.

Varanasi, U., M. Nishimoto, W.L. Reichert and J.E. Stein, 1982. Metabolism and subsequent covalent binding of benzo(a)pyrene to macromolecules in gonads and liver of ripe English sole (Parophrys vetulus). Xenobiotica, 12: 417-425.

Vignier, V. and F. Berthou, 1986. Hepatic mixed-function oxidase activities of plaices (Pleuronectes platessa) as biomonotoring index of the aquatic environment polluted by the Amoco-Cadiz oil spill. In: 16th Annual Symposium on the Analytical Chemistry of Pollutants, Lausanne, March 17-19, 1986. Ecole Polytechnique. Fèdérale de Lausanne, p. 189.

Vodicnik, M.J. and J.J. Lech, 1983. The effect of sex steroids and pregnenolone-16- $\alpha$-carbonitrile on the hepatic microsomal monooxygenase system of rainbow trout. (Salmo gairdneri). J. Steroid Biochem., 18: 323-328.

Walton, D.G., L.L. Fancey, J.M. Green, J.W. Kiceniuk and W.R. Penrose, 1983. Seasonal changes in aryl hydrocarbon hydroxylase activity of a marine fish Tautogolabrus adspersus (Walbaum) with and without petroleum exposure. Comp. Biochem. Physiol., 76C: 247-253.

Werringloer, J., 1978. Assay of formaldehyde generated during microsomal oxidation reactions. In: S. Fleischer and L. Packer (Eds), Methods in Enzymology, Vol LII, Part C. Academic Press, New York, pp. 297-302. 